\title{
Nest construction by a ground-nesting bird represents a potential trade-off between egg crypticity and thermoregulation
}

Paul M. Mayer · Levica M. Smith · Robert G. Ford •

Dustin C. Watterson • Marshall D. McCutchen •

Mark R. Ryan

Published online: 4 March 2009

(c) Springer-Verlag 2009

\section{Erratum to: Oecologia}

\section{DOI 10.1007/s00442-008-1266-9}

Citation of reference Conway and Martin (2000a, b) in text and reference list was published with errors.

The correct citation is given here as Conway and Martin (2000a, b) not as Courtney and Martin (2000a, b).

\section{References}

Conway CJ, Martin TE (2000a) Effects of ambient temperature on avian incubation behavior. Behav Ecol 11:178-188

Conway CJ, Martin TE (2000b) Evolution of passerine incubation behavior: influence of food, temperature, and nest predation. Evolution 54:670-685

The online version of the original article can be found under doi: $10.1007 / \mathrm{s} 00442-008-1266-9$.

P. M. Mayer $(\varangle) \cdot$ R. G. Ford · M. D. McCutchen Office of Research and Development,

US Environmental Protection Agency,

919 Kerr Research Drive, Ada, OK 74820, USA

e-mail: mayer.paul@epa.gov

L. M. Smith · D. C. Watterson

McNair Scholars Program, East Central University,

Ada, OK 74820, USA

M. R. Ryan

School of Natural Resources,

University of Missouri, Columbia, MO 65211, USA

Present Address:

L. M. Smith

Physics Department, Texas A\&M University,

4242 TAMU, College Station, TX 77843-4242, USA

Present Address:

R. G. Ford

Office of Research and Development,

US Environmental Protection Agency,

26 West Martin Luther King Dr.,

Cincinnati, OH 45268, USA 